\title{
Erratum to: Practical application of acid dissociation in monitoring patients treated with adalimumab
}

Francisca Llinares-Tello • José Rosas-Gómez de Salazar · José Miguel Senabre-Gallego • Gregorio Santos-Soler $\cdot$ Carlos Santos-Ramírez $\cdot$ Esteban Salas-Heredia $\cdot$ Xavier Barber-Vallés · Juan Molina-García · AIRE-MB Group

Published online: 13 June 2014

(C) Springer-Verlag Berlin Heidelberg 2014

\section{Erratum to: Rheumatol Int}

DOI 10.1007/s00296-014-3032-0

Unfortunately, one of the units in the below sentence was incorrectly published under the section "Patients and methods". The correct sentence should read as:

Briefly, $20 \mu \mathrm{L}$ of serum was mixed with $100 \mu \mathrm{L}$ of $300 \mathrm{mM}$ acetic acid to a final $\mathrm{pH}$ of 3.0.

The online version of the original article can be found under doi:10.1007/s00296-014-3032-0.

F. Llinares-Tello $(\bowtie) \cdot$ J. Molina-García

Laboratory Department, Marina Baixa Hospital,

Av Jaime Botella Mayor nº 03570 Villajoyosa,

Alicante, Spain

e-mail: paquillinares@eresmas.com

J. Rosas-Gómez de Salazar · J. M. Senabre-Gallego .

G. Santos-Soler · E. Salas-Heredia

Rheumatology Department, Marina Baixa Hospital,

Villajoyosa, Alicante, Spain

C. Santos-Ramírez

Rheumatology Department, Marina Salud Hospital,

Denia, Alicante, Spain

X. Barber-Vallés

CIO-Universidad Miguel Hernández, Elche, Alicante, Spain 